\title{
THE HEBERDEN SOCIETY
}

In a short communication read before the Heberden Society recently, Mr. W. D. Coltart described the condition of degenerative patello-femoral arthritis. Degenerative changes in the patellar articular cartilage are common post-mortem and operative findings, and well marked patello-femoral crepitus is often observed in symptomless knees. Occasionally the condition becomes painful and disabling and cases can be divided into three clinical groups: (1) arthritis of the patello-femoral articulation occurring after a fracture of the patella; (2) a post-traumatic condition without definite fracture; (3) cases of apparently spontaneous origin.

The affection can be recognized by a definite syndrome of: (a) characteristic pain in the patellar area, (b) patellar tenderness, (c) pain referred to the patello-femoral region on active extension of the knee against resistance, (d) complete relief of painful symptoms when the knee is immobilized in plaster and the immediate recurrence of these symptoms when the plaster is removed, (e) a rather remarkable absence of sign of generalized arthritis of the knee, and no radiographic changes.

Conservative treatment is unsuccessful in the majority of cases, and patellectomy is often indicated. At operation the articular cartilage of the patellar is seen to be fibrillated, tufted, and discoloured. Later there is erosion of the cartilage and eburnation of the underlying bone.

Although degenerative patello-femoral arthritis in its turn may give rise to a true osteo-arthritis of the knee, it should at first be regarded as a clinical entity and not simply as part of a generalized affection of the whole joint.

Professor Östen Holsti, University of Helsinki, read a paper on an epidemic of Reiter's disease. The data for it had been collected by his former Registrar, Dr. I. Paronen, and will be published by him as an academic thesis in a supplement to the Acta Medica Scandinavica. The following is a summary of Professor Holsti's paper.

\section{An Epidemic of Reiter's Disease}

In the summer of 1944 an epidemic of Flexner dysentery raged in Finland and affected about 150,000 persons, mostly soldiers on the eastern front. An outbreak of Reiter's disease followed in 0.20 per cent. of the dysentery patients. Within a few months more than 300 cases of Reiter's disease were seen, the great majority in soldiers who as a rule were young. A few women attending hospital or other military departments were, however, also affected. About two-thirds of the cases developed within three weeks, and four-fifths within one month of the onset of dysentery, some even before the latter had cleared up. In the remaining cases the interval was longer, even up to three months.

Most cases were accompanied by fever. This was at times of a septic, at times of a continual chronic type. In some cases the fever disappeared after a few days, only to return later. In two-thirds of the cases the fever disappeared definitively within two, and in four-fifths of the cases within three, weeks. Occasionally we had cases that presented fever for several months.

The erythrocyte sedimentation rate was normal in a few cases. In most cases it was raised to a variable extent, even up to $140 \mathrm{~mm}$. per hour.

Various degrees of leucocyte response were also evenly distributed in our material. In the septic cases values up to 18,000 were seen. In others there was no rise in the granulocytes, the differential blood picture showing increased values only of the lympho- and monocytes. In about a third of the cases there was a marked increase-up to 30 per cent. of the eosinophilic cells, a higher figure than in any other form of arthritis I know of. A slight degree of anaemia was present in some cases.

In the beginning the disease was mostly monosymptomatic. Evenly distributed monosymptomatic forms occurred as eye, joint, and genito-urinary syndromes. Bisymptomatic syndromes appeared in a quarter of the cases. Rarely the disease was trisymptomatic from the beginning. Within three weeks the clinical picture changed completely so that about 70 per cent. were trisymptomatic and about 90 per cent. at least bisymptomatic. Still later, within a period of two or three months, all remaining cases were again of the monosymptomatic type, but now they all presented the picture of a joint disease (Fig. 1).

Fig. 2 shows that the knees and ankles were most frequently affected, but any joint might be the seat of a lesion. A combination of pains and swelling 


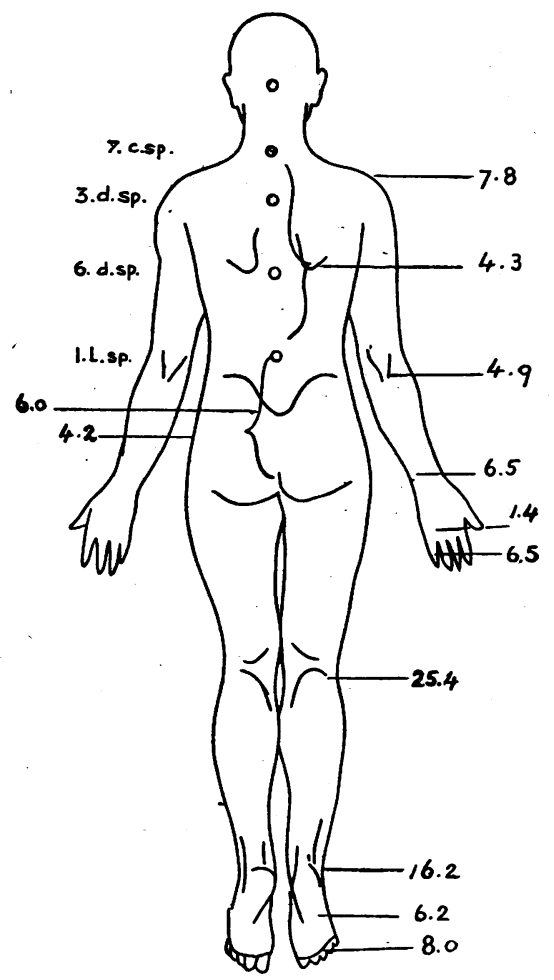

FIG. 1.-The clinical syndromes: $\quad U=$ genito-urinary; $\mathrm{E}=$ eye; $\mathrm{J}=$ joint.

were the commonest syndrome. Large hydrops without pains occurred, however, not infrequently in the knee-joints. Tendo-vaginitis occurred in some cases with or without simultaneous joint lesions. The skin over the affected joints had often a dirty greyish colour. The clinical course of the arthritis was somewhat like that seen in rheumatic fever, as one joint after the other became rapidly affected. It differed, however, in this respect, that at the time when new joints became affected the older lesions had not yet healed. In this respect the arthritis in Reiter's disease was more like that seen in rheumatoid arthritis, especially as there was a tendency to fibrous ankylosis, most marked in the finger joints.

A simple acute conjunctivitis was the most common eye lesion. Kerato-conjunctivitis, iritis, keratoiritis, and ulcus simplex corneae were also seen, although infrequently. In a few cases a sensation of grit in, and water of the eye were the only eye symptoms complained of.

The most frequent genito-urinary lesion was urethritis simplex. Erythema penis was the next most frequent. Bladder and kidney lesions, pro-

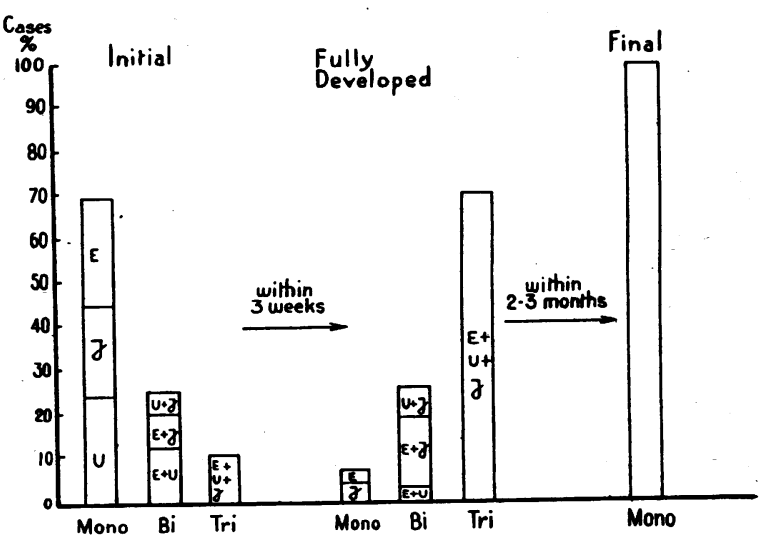

FIG. 2.-Distribution of joint lesions ( \pm tendo-vaginitis).

statitis, orchitis, and epididymitis occurred also, but infrequently. In a few cases there was no urethritis.

Smears from the various secretions never showed any pathogenic bacteria. The serological reactions for known infections were all negative, with the exception of agglutination to Flexner dysentery, which was positive in a variable degree.

In the great majority of cases there was an apparent tendency to spontaneous recovery from all symptoms, although relapses were frequently noted before the final recovery set in. Relapses have been seen to take place even after intervals of a few years. When the patients have become familiar with the significance of their symptoms they began in many cases to realize that they probably had had the disease before, even as long as ten or fifteen years earlier, although it had been unrecognized.

Although our cases occurred in connexion with Flexner dysentery it cannot be excluded that other intestinal infections might be able to cause Reiter's disease. Manson-Bahr seems to believe that Reiter's disease is not new, but another name for polyarthritis enterica. My mind is still quite open in regard to the pathogenesis. I do not know, in spite of our large epidemic, whether Reiter's disease is a disease sui generis or a syndrome developing in certain susceptible persons in association with various infections, perhaps even extra-intestinal ones. That a certain susceptibility or state of allerg is present is seen from the frequent occurrence of eosinophils in the blood as well as in the eye- and genito-urinary secretions in these patients.

The usual symptomatic therapeutic measures used in acute arthritis were given to all patients. Sulphonamides and penicillin were tried in the more difficult cases. The tendency towards spontaneous recovery, however, made any interpretation very 
difficult. We felt that none of these measures had any specific value in treatment. Fever treatment was tried in the later state of the epidemic and it seemed to have a value greater than the abovementioned drugs. During my stay in London I have become acquainted with the effect of Kettering hypertherm in a case of Reiter's disease, and the effect seemed to be still better and more dramatic than what was seen in our cases when the fever was produced with typhoid vaccine given intravenously.

\section{Compte-rendu d'une Réunion de la "Heberden Society" \\ RÉSUMÉ}

W. D. Coltart a divisé les cas d'arthrite dégénérative fémoro-rotulienne en trois groupes: arthrites de l'articulation fémoro-rotulienne (1) après fracture de la rotule; (2) post-traumatiques sans fracture; (3) apparemment spontanées. La maladie pouvant être identifiée par: (a) douleur dans la région rotulienne; (b) hypersensibilité rotulienne; $(c)$ douleur rapportée à la région fémoro-rotulienne lorsque le genou est porté en extrême contre une résistance; $(d)$ soulagement des symptomes par immobilisation et réapparition de ces symptomes lorsqu'on enlève le plâtre; (e) absence d'arthrite généralisée du genou et de modifications radiographiques. Le traitement conservateur échoue généralement et il est souvent nécessaire d'enlever la rotule.

Le Professeur $\mathbf{O}$. Holsti a décrit une épidémie de maladie de Reiter en Finlande chez 0.20 pour cent des malades atteints de dysenterie bacillaire au cours d'une épidémie antérieure. La Fig. 1 montre la répartition des symptomes génito-urinaires, oculaires, et articulaires, et la Fig. 2 la répartition en pourcentages des articulations atteintes. On a appliqué le traitement symptomatique habituel, avec sulfamides et pénicilline pour les cas les plus graves; mais on n'a pas eu l'impression qu'aucune de ces mesures ait une valeur spécifique. La pyrétothérapie semblait plus efficace. L'épidémie sera plus complètement décrite par le Dr. I. Paronen dans Acta Medica Scandinavica.

.

